\title{
Preferential Utilization of Acetate by Astrocytes Is Attributable to Transport
}

\author{
Robert A. Waniewski and David L. Martin \\ Wadsworth Center, New York State Department of Health, Albany, New York 12201-0509
}

Exogenous acetate is preferentially metabolized by astrocytes in the CNS, but the biochemical basis for this selectivity is unknown. We observed that rat cortical astrocytes produce ${ }^{14} \mathrm{CO}_{2}$ from $0.2 \mathrm{~mm}\left[{ }^{14} \mathrm{C}\right]$ acetate at a rate of $0.43 \mathrm{nmol} / \mathrm{min}$ per milligram of protein, 18 times faster than cortical synaptosomes. Subsequent studies examined whether this was attributable to cellular differences in the transport or metabolism of acetate. The activity of acetyl-CoA synthetase, the first enzymatic step in acetate utilization, was greater in synaptosomes than in astrocytes $(5.0$ and $2.9 \mathrm{nmol} / \mathrm{min}$ per milligram of protein), indicating that slower metabolism in synaptosomes cannot be attributed to lack of enzymatic activity. $\left[{ }^{14} \mathrm{C}\right]$ Acetate uptake in astrocytes is rapid and time-dependent and follows saturation kinetics $\left(V_{\max }, 498 \mathrm{nmol} / \mathrm{min}\right.$ per milligram of protein; $K_{\mathrm{m}}, 9.3 \mathrm{~mm}$ ). Uptake is inhibited stereospecifically by L-lactate as well as by pyruvate, fluoroacetate, propionate, and $\alpha$-cyano4-hydroxycinnamate (CHC). Preloading astrocytes with
L-lactate or acetate, but not D-lactate, pyruvate, or glyoxylate, transaccelerates $\left[{ }^{14} \mathrm{C}\right]$ acetate uptake. Acetate uptake by astrocytes appears to be mediated by a carrier with properties similar to that of monocarboxylate transport. In contrast, studies with synaptosomes provided no evidence for timedependent, saturable, transaccelerated, or $\mathrm{CHC}$-inhibitable uptake of $\left[{ }^{14} \mathrm{C}\right]$ acetate. The high rate of transport in astrocytes compared with synaptosomes explains the rapid incorporation of $\left[{ }^{14} \mathrm{C}\right]$ acetate into brain glutamine over glutamate. These findings provide support for the use of acetate as a marker for glial metabolism and suggest that extracellular acetate in the brain generated from acetylcholine and ethanol metabolism is accumulated first by astrocytes.

Key words: acetate transport; acetate metabolism; monocarboxylate transport; astrocytes; synaptosomes; $\alpha$-cyano-4hydroxycinnamate
Acetate has been used as a probe to study brain metabolism. Application of $\left[{ }^{14} \mathrm{C}\right]$ acetate to brain tissue results in the rapid incorporation of label in glutamine with a higher specific activity than in glutamate. In contrast, similar experiments with $\left[{ }^{14} \mathrm{C}\right]$ glucose resulted in the rapid incorporation of label into $\left[{ }^{14} \mathrm{C}\right]$ glutamate and a lower specific activity of glutamine than glutamate (O'Neal and Koeppe, 1966). Such findings have led to the conclusion that acetate is preferentially metabolized in a "small" glutamate pool that is rapidly converted to glutamine, whereas glucose enters a "large" glutamate pool (Van Den Berg et al., 1969). Because glutamine is synthesized primarily within astrocytes (Norenberg and Martinez-Hernandez, 1979), it has been further proposed that acetate is preferentially used by astrocytes over neurons (Fonnum, 1985). Autoradiographic studies with labeled acetate have provided additional evidence that astrocytes preferentially use acetate (Minchin and Beart, 1975; Muir et al., 1986). The incorporation of ${ }^{13} \mathrm{C}$ from acetate into glutamate, glutamine, GABA, citrate, and lactate was examined in astrocyte and neuronal cultures (Sonnewald et al., 1993). Neurons incubated for $20 \mathrm{hr}$ showed no enrichment of ${ }^{13} \mathrm{C}$ in any of these metabolites, whereas astrocytes incubated for $48 \mathrm{hr}$ displayed a significant enrichment. $\left[{ }^{13} \mathrm{C}\right]$ Acetate is now routinely used to

\footnotetext{
Received Jan. 20, 1998; revised April 29, 1998; accepted May 1, 1998.

We thank Tristan Mueck and Roger Benson for technical assistance and the Biochemistry Core for the use of their equipment.

Correspondence should be addressed to R. A. Waniewski, Wadsworth Center, Empire State Plaza, P.O. Box 509, Albany, NY 12201-0509.

Copyright (C) 1998 Society for Neuroscience $0270-6474 / 98 / 185225-09 \$ 05.00 / 0$
}

examine glial metabolism in the brain and NMR studies have verified the selective metabolism of acetate by astrocytes (BadarGoffer et al., 1990; Cerdan et al., 1990; Chapa et al., 1995).

Although it is widely accepted that astrocytes preferentially metabolize acetate in comparison to neurons, no studies have directly addressed the biochemical basis for this difference between the two cell types. There are at least two possible mechanisms that could account for the differential utilization of acetate. One is that astrocytes possess a specialized transport system for acetate that is absent or much less active in neurons. The other possibility is that neurons lack the enzymatic step necessary for acetate metabolism.

The principal entry point for acetate into metabolism in vertebrates is its conversion to acetyl-CoA by acetyl-CoA synthetase (acetate-CoA ligase; EC 6.2.1.1); the acetyl-CoA then enters the TCA cycle by condensing with oxaloacetate to form citrate. Labeled carbon from $\left[{ }^{14} \mathrm{C}\right]$ acetate reaches glutamate by transamination of radiolabeled 2-oxoglutarate formed in the TCA cycle, and the glutamate is converted to glutamine primarily in astrocytes. The labeled carbon in 2-oxoglutarate that is not transaminated to glutamate is further metabolized in the TCA cycle and eventually exits the cycle primarily in the form of $\mathrm{CO}_{2}$.

The purpose of the present study was to determine the biochemical basis for the preferential utilization of acetate by astrocytes versus synaptosomes. The results indicate that transport and not metabolism is the important factor. Synaptosomes have more acetyl-CoA synthetase activity than astrocytes, but acetate uptake is much more rapid in astrocytes than synaptosomes. Acetate uptake by astrocytes has many of the properties of the proton-coupled, monocarboxylate transport process found in 
erythrocytes, heart, kidney, and skeletal muscle cells (Poole and Halestrap, 1993).

\section{MATERIALS AND METHODS}

Astrocyte cultures. Primary cultures of astrocytes were prepared from cortices of 2- to 3-d-old rats (Frangakis and Kimelberg, 1984). Brain tissue was removed from pups. Cells were plated in 24-well trays or 100 $\mathrm{mm}$ plates (Falcon) at a density of $10-20,000$ cells $/ \mathrm{cm}^{2}$. Cells were maintained in Eagle's Medium supplemented with $10 \%$ fetal bovine serum, penicillin, and streptomycin at $36^{\circ} \mathrm{C}$ in a humidified incubator with $5 \% \mathrm{CO}_{2}$ and $95 \%$ air and were used in experiments after 3-4 weeks. At this point the cells had formed a confluent monolayer of high density; glial fibrillary acidic protein immunostaining indicated that $>95 \%$ were astrocytes.

Preparation of synaptosomes. Adult rats were lightly anesthetized with $\mathrm{CO}_{2}$ and decapitated. Brains were rapidly removed and cooled in $0.9 \%$ saline on ice. The cerebral cortex was dissected, weighed, and homogenized in $0.32 \mathrm{M}$ sucrose. Synaptosomes that are relatively free of extrasynaptosomal mitochondria and glial contamination were prepared by the method of Löscher et al. (1985). Synaptosomes prepared in this way have been assayed for glutamine synthesis (Battaglioli and Martin, 1990). They produce glutamine at $<5 \%$ of the rate found in astrocyte cultures (Waniewski, 1992), indicating low astrocytic contamination.

Measurement of $\left[{ }^{14} \mathrm{C}\right]$ acetate oxidation to ${ }^{14} \mathrm{CO}_{2}$. To measure acetate metabolism, astrocytes or synaptosomes were incubated at $37^{\circ} \mathrm{C}$ in 24 -

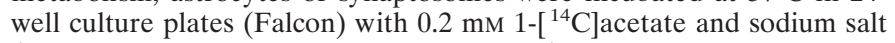
(54.7 $\mathrm{mCi} / \mathrm{mmol}$; Sigma, St. Louis, MO) in oxygenated, glucosecontaining HEPES-buffered HBSS (Martin and Shain, 1979). Individual wells were fitted with specially made Plexiglas adaptors and serum tube stoppers that held a small cup containing $50 \mu \mathrm{l}$ benzethonium hydroxide (Sigma) to trap the ${ }^{14} \mathrm{CO}_{2}$. The reaction was stopped by injecting $0.2 \mathrm{M}$ citric acid through the stopper into the incubation medium. The tray was heated at $60^{\circ} \mathrm{C}$ for 15 min to volatilize $\mathrm{CO}_{2}$ dissolved in the medium, and the trapped ${ }^{14} \mathrm{CO}_{2}$ was analyzed by scintillation counting. Wells without cells and addition of citric acid to cells at the start of the incubation period gave the same results and served as blank controls.

Measurement of acetyl-CoA synthetase activity. Acetyl-CoA synthetase was measured by following the formation of $\left[{ }^{14} \mathrm{C}\right]$ acetyl-CoA from $1-\left[{ }^{14} \mathrm{C}\right]$ acetate $(0.6 \mathrm{~mm})$ and coenzyme $\mathrm{A}(0.6 \mathrm{mM})$ in the presence of ATP $(3 \mathrm{~mm})$ and $\mathrm{Mg}^{2+}$ in potassium phosphate buffer $(50 \mathrm{~mm}, \mathrm{pH} 8.0)$ (Reijnierse et al., 1975). The product was separated from the substrate by collection on ion exchange filters (DE81; Whatman, Maidstone, UK; $2.4 \mathrm{~cm}$ ) and washed with $1 \mathrm{ml}$ of acetic acid (2\%) (Roughan and Ohlrogge, 1994).

For assay, astrocytes were scraped from $100 \mathrm{~mm}$ tissue culture plates (Falcon) with a rubber policeman and collected in buffer on ice. Cells, cortical tissues, and synaptosomes were homogenized in Tris-buffered, $0.32 \mathrm{M}$ sucrose containing $\mathrm{MgCl}_{2}(27 \mathrm{~mm}), 1.25 \%$ Triton $\mathrm{X}-100$, and bovine serum albumin (BSA) $(4.5 \mathrm{mg} / \mathrm{ml})$. Enzyme activity was measured by incubating homogenates at $37^{\circ} \mathrm{C}$ for $15,30,45$, and $60 \mathrm{~min}$ and normalized to protein content (Lowry et al., 1951).

Analysis of transport. Acetate transport was measured under conditions similar to those for measuring radiolabeled lactate transport by the monocarboxylate transporter (Poole and Halestrap, 1993). The incubation medium was oxygenated HEPES-buffered balanced salt solution without glucose or additional anions other than chloride (in mM: 10 HEPES, 150 sodium chloride, 5 potassium chloride, 1 calcium chloride, and 1 magnesium chloride, pH 7.4, with $1 \mathrm{NaOH}$; Garcia et al., 1994).

Multiwell (24) culture plates containing astrocytes were individually corked and transferred to a temperature-controlled water bath at $4^{\circ} \mathrm{C}$. Cells were rapidly rinsed $(3-5 \mathrm{sec})$ with five washes of buffer and then either incubated immediately with acetate or allowed to preincubate for $15 \mathrm{~min}$ at $4^{\circ} \mathrm{C}$. The preincubation medium was removed with three washes before adding $\left[{ }^{14} \mathrm{C}\right]$ acetate. When tested, transport inhibitors were added to the cells in the medium containing the $1-\left[{ }^{14} \mathrm{C}\right]$ acetate. To stop the reaction, the cells were washed three times with fresh ice-cold buffer. The background uptake was determined by incubating cells for 0 min. This was done by washing with fresh ice-cold buffer immediately after adding the $1-\left[{ }^{14} \mathrm{C}\right]$ acetate. The cells were then treated with $300 \mu \mathrm{l}$ of $1 \mathrm{M} \mathrm{NaOH}$ to stop metabolism and prevent evolution of acetic acid or volatile acidic metabolites. After sitting overnight at $37^{\circ} \mathrm{C}$, solubilized cells were transferred to scintillation vials, and the wells were rinsed two times with $450 \mu \mathrm{l}$ of water. An aliquot was taken to measure the protein content (Bradford, 1976) and the remainder was analyzed for ${ }^{14} \mathrm{C}$ by scintillation counting. The $0 \mathrm{~min}$ values for uptake were then subtracted from the $15 \mathrm{sec}$ time points in each experiment, and the difference was expressed in moles of acetate uptake per min $\times$ milligrams of protein. Synaptosomes were incubated with $1-\left[{ }^{14} \mathrm{C}\right]$ acetate for the indicated times at 4 or $37^{\circ} \mathrm{C}$, diluted into ice-cold medium containing $\alpha$-cyano-4hydroxycinnamate (CHC) $(10 \mathrm{~mm})$, and immediately centrifuged through silicone oil (SF1250, General Electric, Waterford, NY) at room temperature using the inhibitor-stop procedure (Poole and Halestrap, 1993 ) to terminate uptake and prevent efflux. When the centrifugation step was done in a cold room, the oil viscosity was too high to allow the synaptosomes through. The $0 \mathrm{~min}$ points were obtained by adding an aliquot of the synaptosome suspension directly to the centrifuge tubes containing $1-\left[{ }^{14} \mathrm{C}\right]$ acetate and $\mathrm{CHC}$ and immediately starting the centrifuge for each sample. The incubation medium and oil layers were removed by vacuum aspiration. The synaptosomal pellets were dissolved overnight in $1 \mathrm{M} \mathrm{NaOH}$ and neutralized with $1 \mathrm{M} \mathrm{HCl}$, and ${ }^{14} \mathrm{C}$ was determined by scintillation counting.

$\left[{ }^{14} \mathrm{C}\right]$ Glutamate uptake was measured in parallel with $1-\left[{ }^{14} \mathrm{C}\right]$ acetate uptake using the same synaptosomal suspensions.

Determination of sucrose space. $\left[{ }^{14} \mathrm{C}(\mathrm{U})\right]$ Sucrose $(540 \mathrm{mCi} / \mathrm{mmol} ; \mathrm{Am}-$ ersham, Arlington Heights, IL) was purified by TLC (Haldorsen, 1977) and used to estimate the entrapped fluid volume in the synaptosomal pellet. Synaptosomes in suspension at five different dilutions were incubated at $4{ }^{\circ} \mathrm{C}$ with $\left[{ }^{14} \mathrm{C}(\mathrm{U})\right]$ sucrose and centrifuged through silicone oil with procedures identical to those used for the 0 min incubation of synaptosomes with $\left[{ }^{14} \mathrm{C}\right]$ acetate.

Protein analysis. Protein was measured by the Coomassie blue dyebinding assay (Bradford, 1976) or by the method of Lowry et al. (1951) with BSA as a standard. Estimates of protein obtained with the Lowry method were approximately two times higher than those obtained with the Bradford method in the same synaptosomal suspensions.

Statistics. Experimental treatment groups were compared by one-way ANOVA. When a significant $F$ value was found at the 0.05 level, individual comparisons were made $a$ posteriori by $t$ tests with the Bonferroni correction.

\section{RESULTS \\ $\left[{ }^{14} \mathrm{C}\right]$ Acetate metabolism to ${ }^{14} \mathrm{CO}_{2}$ by synaptosomes and astrocytes}

At $37^{\circ} \mathrm{C}$, astrocytes produced ${ }^{14} \mathrm{CO}_{2}$ from $0.2 \mathrm{~mm} 1-\left[{ }^{14} \mathrm{C}\right]$ acetate at an average rate $(25.8 \pm 1.5 \mathrm{nmol} / \mathrm{hr}$ per milligram of protein $)$ 18 -fold greater than synaptosomes $(1.4 \pm 0.03 \mathrm{nmol} / \mathrm{hr}$ per milligram of protein) (Fig. 1). With both preparations there was a substantial lag in the production of ${ }^{14} \mathrm{CO}_{2}$, probably because the labeled carbon in $1-\left[{ }^{14} \mathrm{C}\right]$ acetate must complete one turn of the TCA cycle before it can be released as ${ }^{14} \mathrm{CO}_{2}$.

\section{Acetyl-CoA synthetase activity}

The synthesis of $\left[{ }^{14} \mathrm{C}\right]$ acetyl-CoA from $1-\left[{ }^{14} \mathrm{C}\right]$ acetate in homogenates of cerebral cortex, cortical astrocytes, and cortical synaptosomes increased linearly with time at $37^{\circ} \mathrm{C}$ (Fig. 2). The enzyme activity during the first $15 \mathrm{~min}$ was $5.2 \pm 0.2 \mathrm{nmol} / \mathrm{min}$ per milligram of protein in cortex, $4.9 \pm 0.3 \mathrm{nmol} / \mathrm{min}$ per milligram of protein in synaptosomes, and $2.9 \pm 0.2 \mathrm{nmol} / \mathrm{min}$ per milligram of protein in astrocyte cultures. These results indicate that acetylCoA synthetase is not selectively enriched in astrocytes over cortical synaptosomes or whole cortex homogenates.

\section{Acetate transport by astrocytes}

Acetate uptake measurements were performed at $4^{\circ} \mathrm{C}$ because, at this temperature, the reaction was slow enough to obtain reliable kinetic estimates. Total uptake at physiological temperatures was similar to that at $4^{\circ} \mathrm{C}$ but simply too fast to determine initial rates. When uptake was measured at $37^{\circ} \mathrm{C}$, the increase in intracellular $\left[{ }^{14} \mathrm{C}\right]$ acetate was not linear, even after the shortest time point that could be used in practice $(15 \mathrm{sec})$. At $4^{\circ} \mathrm{C}$ the increase in uptake was linear with time for $1 \mathrm{~min}$. To measure initial rates, all subsequent transport experiments with astrocytes were performed for $15 \mathrm{sec}$ at $4^{\circ} \mathrm{C}$. This low temperature and short incu- 


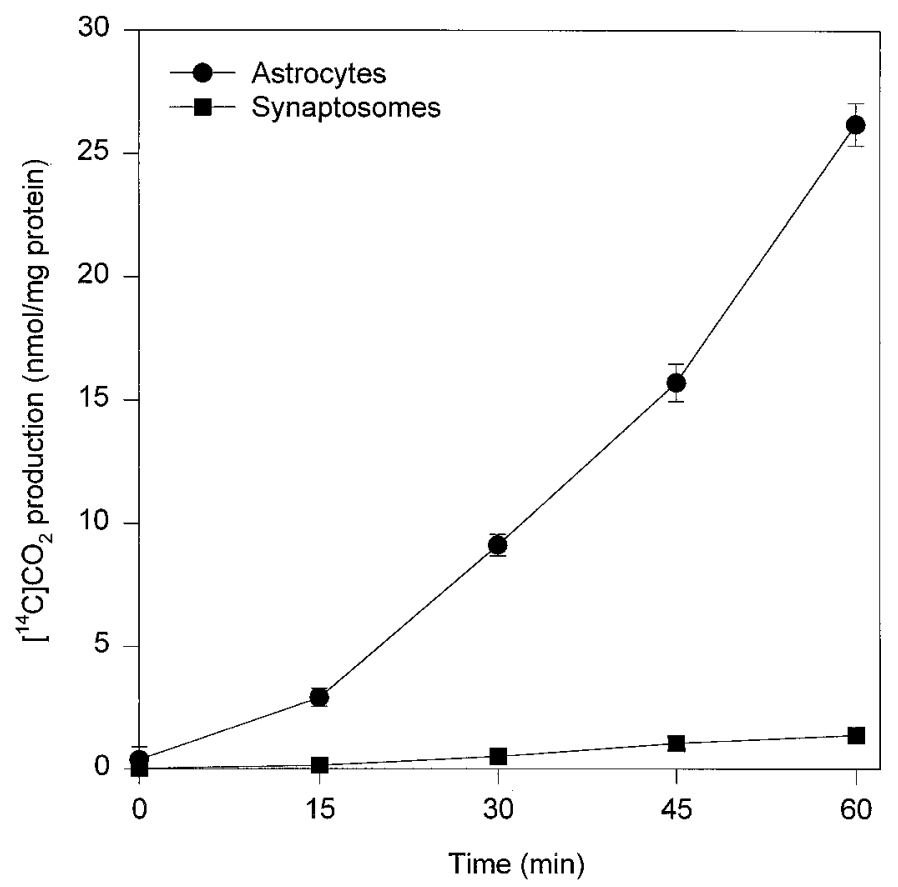

Figure 1. Astrocytes produce ${ }^{14} \mathrm{CO}_{2}$ from $1-\left[{ }^{14} \mathrm{C}\right]$ acetate much more rapidly than do synaptosomes. Both preparations were incubated with 0.2 mM sodium acetate under identical conditions in an oxygenated, glucosecontaining, HEPES-buffered HBSS at $37^{\circ} \mathrm{C}$ for the indicated times. Data points represent the mean $\pm \mathrm{SD}$ of three determinations. Synaptosomal production of ${ }^{14} \mathrm{CO}_{2}$ was significantly less than astrocytic production at all time points after $0 \mathrm{~min} ; p<0.01$.

bation time presumably also minimized metabolism and subsequent loss of label from the cells.

Because the incubation time was so short, it was crucial to remove extracellular acetate as rapidly and thoroughly as possible without affecting the retention of accumulated acetate. Various rinse procedures were used in an attempt to prevent the loss of the accumulated acetate from the astrocytes. Empirical tests with empty wells indicated that the rinse procedure was optimal using three rinses with $1 \mathrm{ml}$ of ice-cold incubation medium. This could be completed in $<5 \mathrm{sec}$. Transport inhibitors were added to the rinse medium to determine whether they would prevent washout of label from cells as was observed by other investigators (Tildon et al., 1993; Poole and Halestrap, 1993). Inclusion of $0.5 \mathrm{~mm}$ 4,4'-diisothiocyanatostilbene-2,2'-disulfonic acid (DIDS), $10 \mathrm{~mm}$ $\mathrm{HgCl}_{2}$, or $0.6 \mathrm{~mm}$ phloretin in the rinse buffer did not improve the intracellular retention of acetate over buffer alone. Therefore, inhibitors were not included in subsequent studies.

Inclusion of glucose in the incubation medium with $\left[{ }^{14} \mathrm{C}\right] \mathrm{ac}-$ etate did not improve uptake over that measured in glucose-free medium. Glucose-free medium was used to reduce the formation of endogenous, exchangeable substrates for transport. Acetate uptake was dramatically reduced when astrocytes were preincubated in glucose-free medium for 15 min or longer compared with nonpreincubated cells (Fig. 3). This resembles the effect of preincubation on lactate uptake by astrocytes (Tildon et al., 1993). When astrocytes were allowed to preincubate for $15 \mathrm{~min}$ in the presence of L-lactate $(10 \mathrm{~mm})$, acetate uptake was restored to the level observed without preincubation (Fig. 3). The stimulation of lactate uptake by preincubation with L-lactate has been explained by transacceleration and is characteristic of the proton-coupled monocarboxylate transport process (Poole and Halestrap, 1993).

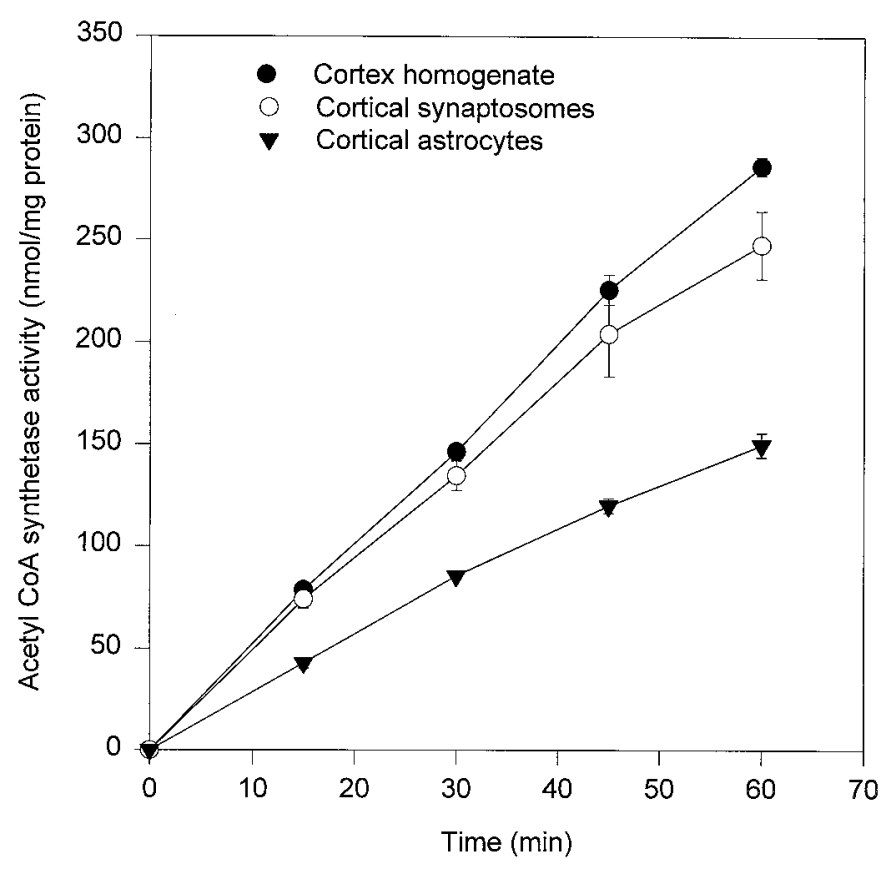

Figure 2. Acetyl-CoA synthetase activity is greater in synaptosomes than astrocytes. Data points represent the mean \pm SD. Three preparations of cortex and synaptosomes were used. Three plates of astrocytes were pooled and a single preparation was used. This experiment was repeated once for astrocytes and cortex, and the same results were obtained.

The specificity of transacceleration of pyruvate transport has been examined in peripheral tissues; pyruvate and L-lactate stimulated pyruvate uptake, D-lactate and glyoxylate did not (Garcia et al., 1994). In astrocytes the effects of transacceleration on acetate uptake were similar with the exception of pyruvate. Acetate uptake was increased after preloading with $10 \mathrm{~mm}$ L-lactate but not with pyruvate or glyoxylate (Fig. 3). Preincubation with acetate increased $1-\left[{ }^{14} \mathrm{C}\right]$ acetate uptake, whereas preincubation with D-lactate had no effect (data not shown). For all subsequent experiments, astrocytes were preincubated with L-lactate for 15 min and then washed three times before the addition of $1-\left[{ }^{14} \mathrm{C}\right]$ acetate.

Using the conditions established above, astrocytes were incubated with a range of acetate concentrations to determine the kinetics of $\left[{ }^{14} \mathrm{C}\right]$ acetate uptake. The resulting uptake was best fit by a saturation curve yielding a calculated $K_{\mathrm{m}}$ of $9.3 \pm 5.0 \mathrm{~mm}$ and a $V_{\max }$ of $498 \pm 162 \mathrm{nmol} / \mathrm{min}$ per milligram of protein (average $\pm \mathrm{SD}$ of three separate experiments). The results of a representative experiment are shown in Figure 4. An EadieHofstee plot of the data (inset) was linear, indicating a single kinetic component. Higher acetate concentrations were not used because of the complications of possible osmotic effects. In another experiment, lower acetate concentrations (50 $\mu \mathrm{M}$ to $2 \mathrm{mM})$ provided no evidence for saturation of an additional high-affinity component of uptake. Acetate was used at a concentration of 0.2 $\mathrm{mm}$ for all subsequent studies. This concentration is well below the $K_{\mathrm{m}}$ and is at the physiological level of acetate in the blood.

Several compounds were tested for their ability to inhibit acetate uptake. These included substrates for the monocarboxylate transporter: L-lactate, pyruvate, and propionate; a specific inhibitor of the monocarboxylate transporter, CHC (Halestrap and Denton, 1974); the anion-transport inhibitors DIDS and 


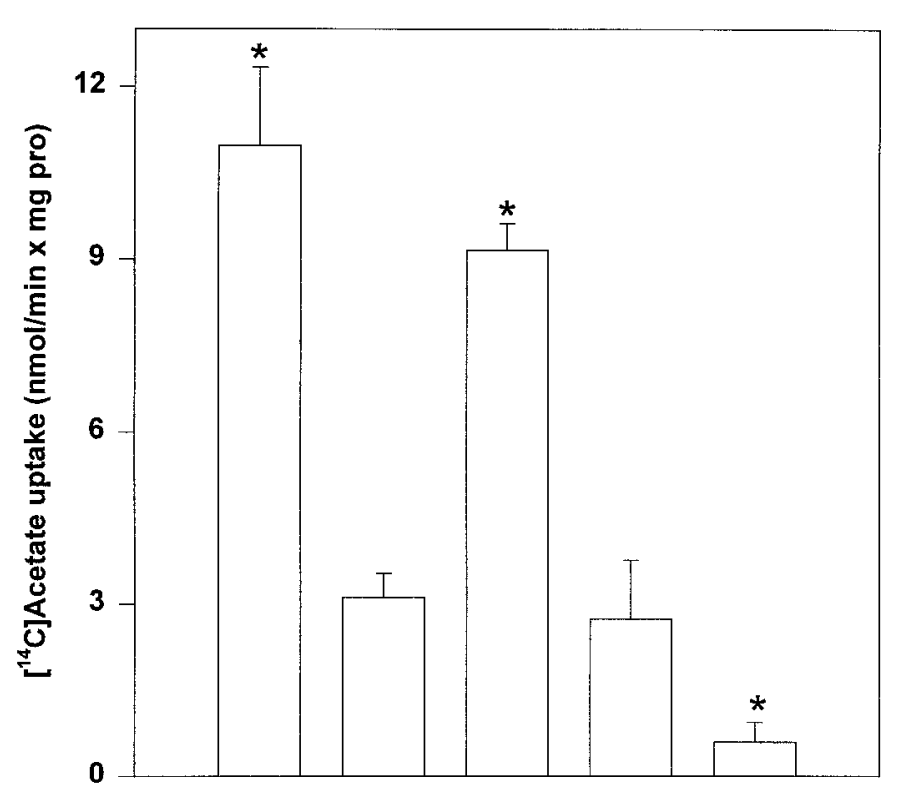

No preinc. Buffer L-Lactate Pyruvate Glyoxylate

15 minute preincubation with above

Figure 3. Preincubation conditions strongly affect $\left[{ }^{14} \mathrm{C}\right]$ acetate uptake by astrocytes. Astrocytes that were not preincubated (No preinc.) were rinsed on transfer from the culture incubator, and $\left[{ }^{14} \mathrm{C}\right]$ acetate was immediately added to the wells. The cells in the other treatment groups were preincubated for 15 min at $4^{\circ} \mathrm{C}$ with glucose-free buffer alone or buffer containing $10 \mathrm{~mm}$ L-lactate, pyruvate, or glyoxylate. After preincubation, cells were rinsed three times with fresh buffer alone before adding medium containing $\left[{ }^{14} \mathrm{C}\right]$ acetate. The initial rate of uptake was measured after a $15 \mathrm{sec}$ incubation at $4{ }^{\circ} \mathrm{C}$ with $0.2 \mathrm{~mm}\left[{ }^{14} \mathrm{C}\right]$ acetate. Bars represent mean $\pm \mathrm{SD}$ for triplicate determinations. Uptake was significantly reduced by preincubating cells in buffer alone compared with not preincubating cells in buffer. ${ }^{*}$ Significant differences from cells preincubated in buffer alone; $p<0.05$.

ethacrynic acid; and several other monocarboxylates, including D-lactate. The effects of a range of concentrations of $\mathrm{CHC}$ and $\mathrm{L}$ and D-lactate are presented in Figure 5. CHC was the most potent of the compounds tested. L-Lactate produced significant inhibition at 10 and $20 \mathrm{~mm}$. D-Lactate produced no significant inhibition of uptake, even at $20 \mathrm{~mm}$. Using the difference between control (no inhibitor present) and maximal inhibition with $\mathrm{CHC}$ as the total inhibitory effect, the $\mathrm{IC}_{50}$ values were estimated from the graph to be (in $\mathrm{mm}$ ): 0.35 for $\mathrm{CHC}, 10$ for L-lactate, and $>20$ for D-lactate.

The concentration-response relationships for uptake inhibition by pyruvate and fluoroacetate are shown in Figure 6. Pyruvate was more effective than fluoroacetate and produced more inhibition at $20 \mathrm{~mm}$ than $\mathrm{CHC}$ at $10 \mathrm{~mm}$. Pyruvate produced significant inhibition at all tested concentrations from 1 to $20 \mathrm{~mm}$. Fluoroacetate produced significant inhibition at $5 \mathrm{~mm}$ and at higher concentrations. DIDS significantly inhibited uptake at $1 \mathrm{~mm}$ (by $24 \%$ ) but did not produce greater inhibition at 2 or $5 \mathrm{~mm}$ (data not shown). The $\mathrm{IC}_{50}$ values (relative to the inhibition produced by $\mathrm{CHC}$ ) were (in $\mathrm{mm}$ ): 1 for pyruvate, 7 for fluoroacetate, and $>5$ for DIDS. The concentrations found to inhibit uptake are high but in line with the theoretical calculated concentrations required to inhibit such a low-affinity transporter based on a competitive inhibition model.

Additional compounds were tested for uptake inhibition at 1

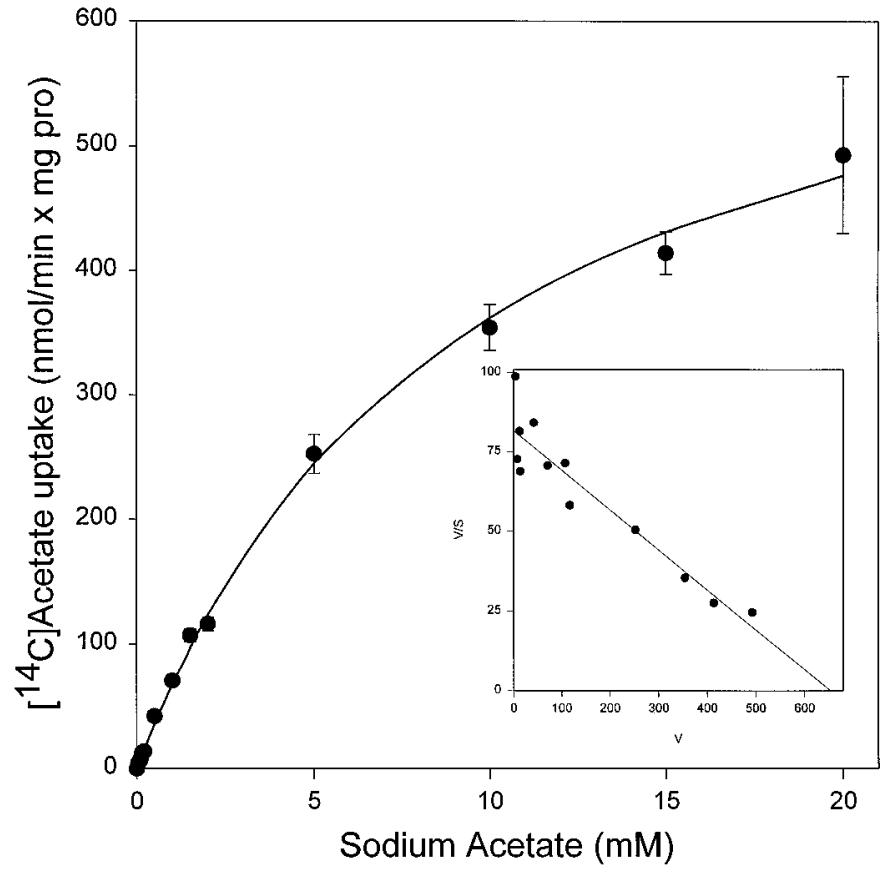

Figure 4. Uptake by astrocytes of $\left[{ }^{14} \mathrm{C}\right]$ acetate at concentrations ranging from 0.2 to $20 \mathrm{~mm}$ at $4^{\circ} \mathrm{C}$. Data points are mean $\pm \mathrm{SD}$ of triplicate determinations. The line represents a fit of the data to the MichaelisMenten equation. This fit provided a calculated $K_{\mathrm{m}}$ of $9.3 \pm 3.0 \mathrm{~mm}$ and a $V_{\max }$ of $648 \pm 102 \mathrm{nmol} / \mathrm{min}$ per milligram of protein. An EadieHofstee plot of the average uptake at each concentration (inset) was linear, indicating a single kinetic component. This experiment was repeated three times, and similar results were obtained.

mM with $0.2 \mathrm{~mm} 1-\left[{ }^{14} \mathrm{C}\right]$ acetate to elucidate the mechanism of acetate uptake. The rank order of efficacy and the percent inhibition in parentheses for all compounds tested at $1 \mathrm{~mm}$ are as follows: CHC (68 $\pm 16 \%)$, pyruvate $(47 \pm 10 \%)$, ethacrynic acid $(39 \pm 17 \%)$, fluoroacetate $(31 \pm 26 \%)$, DIDS $(24 \pm 7 \%)$, and propionate $(14 \pm 8 \%)$. Those found to be ineffective at $1 \mathrm{~mm}$ were L-lactate, D-lactate, malate, glyoxylate, and 2-propylpentanoic acid. Ethacrynic acid is a phenoxyacetic acid that inhibits ATPdependent chloride transport in the brain (Shiroya et al., 1989). The sodium salt of 2-propylpentanoic acid (sodium valproate) is an anticonvulsant monocarboxylate (Gale and Iadarola, 1980). Glyoxylate and malate do not inhibit the monocarboxylate transporter in other systems. DIDS is an inhibitor of anion exchange at low concentrations and inhibits the monocarboxylate transporter at higher concentrations. The pharmacology of inhibition of acetate transport by these compounds in astrocytes is very similar to that of the monocarboxylate transporter studied in other tissues (Poole and Halestrap, 1993).

\section{Acetate transport by synaptosomes}

$\left[{ }^{14} \mathrm{C}\right]$ Acetate uptake in synaptosomes did not increase with time of incubation at 4 or $37^{\circ} \mathrm{C}$ (Fig. 7). The time-independent association observed at $37^{\circ} \mathrm{C}$ was unaffected by addition of $10 \mathrm{~mm}$ CHC (Fig. 7). Preloading synaptosomes for $15 \mathrm{~min}$ with $1 \mathrm{~mm}$ L-lactate did not increase $\left[{ }^{14} \mathrm{C}\right.$ ]acetate uptake at $4{ }^{\circ} \mathrm{C}$ (data not shown). To demonstrate that the synaptosomes used in these studies were intact and capable of uptake, they were also tested for their ability to take up glutamate (Fig. 7). $\left[{ }^{14} \mathrm{C}\right]$ Glutamate uptake was similar to that observed previously (Waniewski and Martin, 1983).

The amount of $\left[{ }^{14} \mathrm{C}\right]$ acetate associated with synaptosomes at 0 


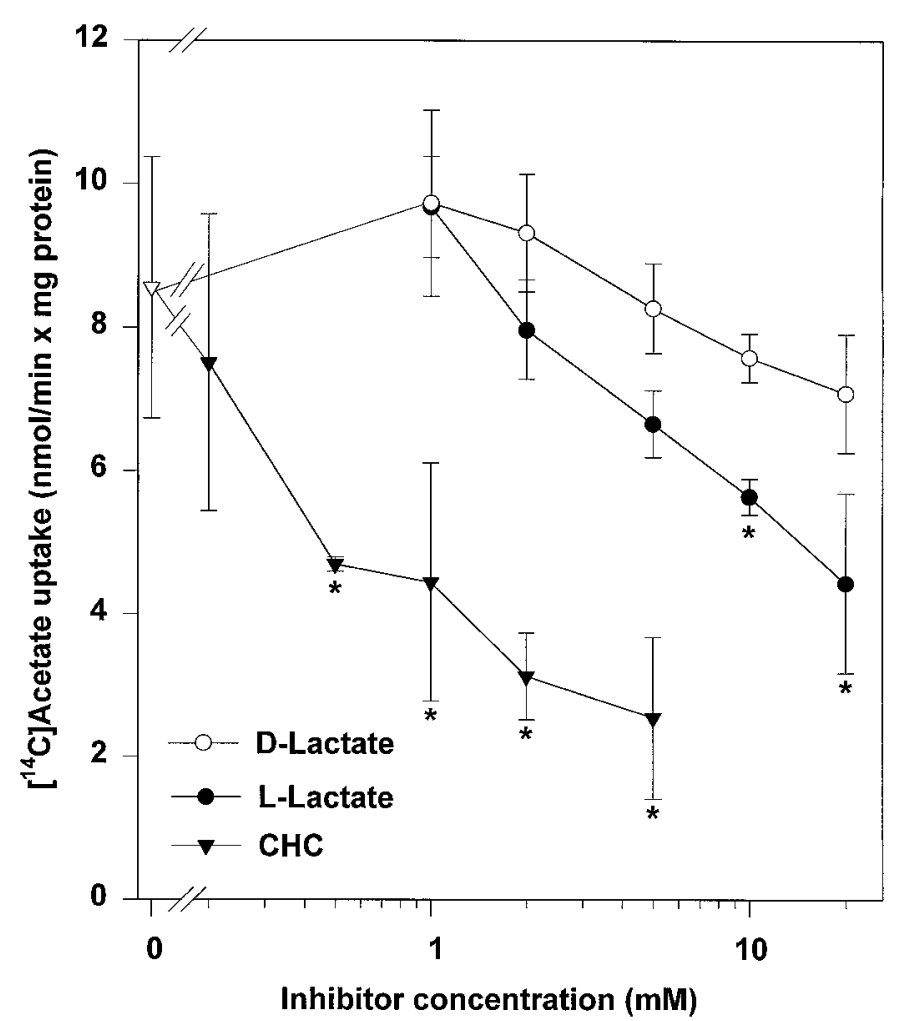

Figure 5. Effect of increasing concentrations of L-lactate, D-lactate, and $\mathrm{CHC}$ on $\left[{ }^{14} \mathrm{C}\right]$ acetate uptake by astrocytes at $4^{\circ} \mathrm{C}$. Individual compounds were added to the cells simultaneously with $0.2 \mathrm{~mm}\left[{ }^{14} \mathrm{C}\right]$ acetate after a 15 min preincubation with $10 \mathrm{~mm}$ L-lactate. Data points represent the mean \pm SD $(n=4)$ for each concentration. Separate controls were included for each compound. This experiment was repeated and similar results were obtained. *Significant difference from control uptake; $p<0.05$.

min was $3.7 \pm 0.3 \mathrm{nmol} / \mathrm{mg}$ protein at $4^{\circ} \mathrm{C}$ and $3.6 \pm 2.1 \mathrm{nmol} / \mathrm{mg}$ protein at $37^{\circ} \mathrm{C}$ and did not change significantly with increasing time of incubation (Fig. 7). One possible mechanism for this association is the rapid movement of $\left[{ }^{14} \mathrm{C}\right]$ acetate into the synaptosomes by passive diffusion. Acetate, the predominant anionic form of the molecule at $\mathrm{pH} 7.4$, is relatively impermeant. Diffusion of the undissociated acid (acetic acid) across lipid bilayers has a permeability coefficient of $6.6 \times 10^{-3} \mathrm{~cm} / \mathrm{sec}$ at $22^{\circ} \mathrm{C}$ (Walter and Gutknecht, 1984). At pH 7.4, the undissociated acid represents $0.23 \%$ of the total acetate $\left(\mathrm{p} K_{\mathrm{a}}=4.76\right)$ and the effective permeability coefficient would be $1.5 \times 10^{-5} \mathrm{~cm} / \mathrm{sec}$. Assuming the synaptosome membranes have the same permeability as the lipid bilayers, with an estimated radius of $1 \mu \mathrm{m}$, the half time for acetate entry would be $\sim 2 \mathrm{sec}$ at $22^{\circ} \mathrm{C}$. Therefore, even at $4^{\circ} \mathrm{C}$, diffusion could be rapid enough to approach equilibrium for extrasynaptosomal and intrasynaptosomal acetate-acetic acid within the time it takes to perform a 0 min incubation $(<5 \mathrm{sec})$. The cytoplasmic $\mathrm{pH}$ in synaptosomes is reported to be $0.27 \mathrm{pH}$ units more acidic than the extracellular medium when a bicarbonate-free HEPES-buffered solution is used (SánchezArmass et al., 1994). This $\mathrm{pH}$ difference would shift the equilibrium for acetate to the extracellular space producing an intracellular acetate concentration of $108 \mu \mathrm{M}$ at the extracellular concentration of $200 \mu \mathrm{M}$. Based on the intrasynaptosomal volume calculated by Marchbanks (1975), the intrasynaptosomal concentration of acetate caused by diffusion would reach a maximum of $714 \mathrm{pmol} / \mathrm{mg}$ protein at equilibrium. This would account for $20 \%$ of the association observed at $0 \mathrm{~min}$.

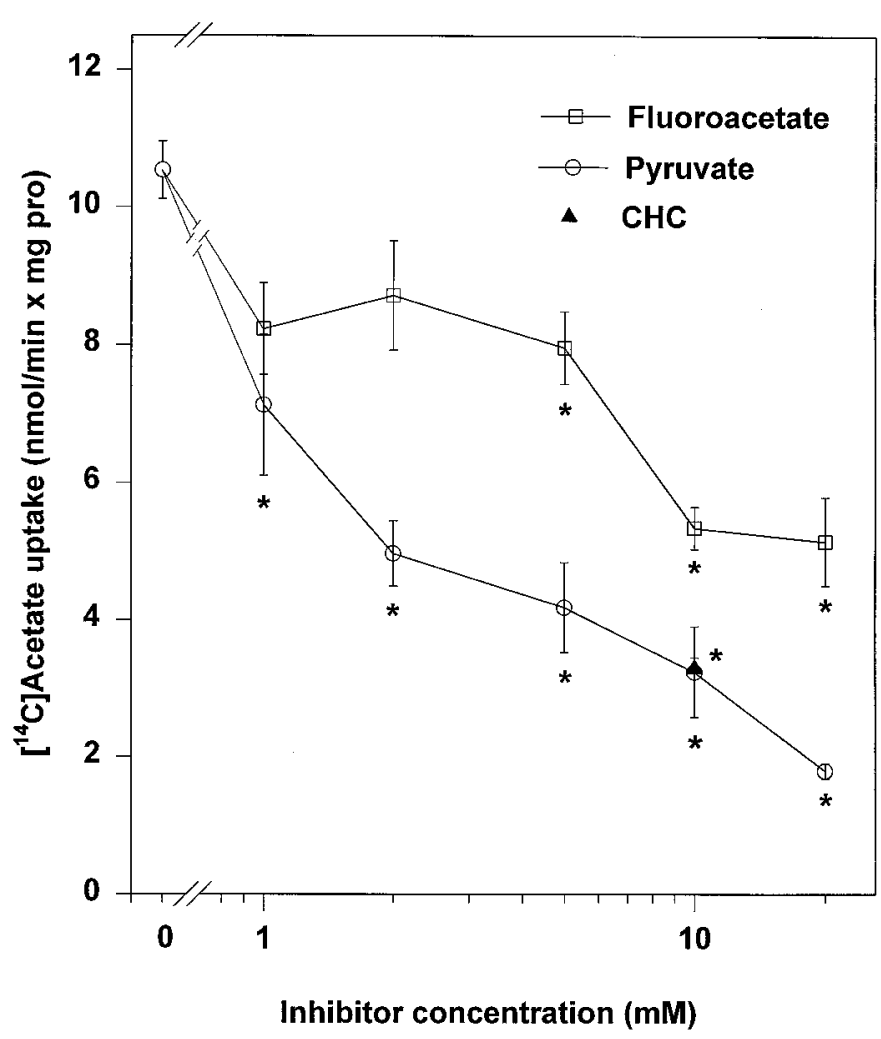

Figure 6. Effect of pyruvate, fluoroacetate, and $\mathrm{CHC}$ on $\left[{ }^{14} \mathrm{C}\right]$ acetate uptake by astrocytes at $4^{\circ} \mathrm{C}$. This experiment was performed and is presented as described in the legend to Figure 5. CHC was only tested at $10 \mathrm{~mm}$ to allow comparisons between experiments.

Similarly, the intracellular $\mathrm{pH}$ in mouse astrocytes is 6.68 when the extracellular $\mathrm{pH}$ is 7.35 in bicarbonate-free HEPES-buffered solutions (Wuttke and Walz, 1990). This $\mathrm{pH}$ difference would yield an intracellular concentration of $43 \mu \mathrm{M}$. Based on the intracellular volume of attached astroglial cells (Waniewski et al., 1991), the calculated diffusional component in astrocytes yields an equilibrium concentration of acetate of $214 \mathrm{pmol} / \mathrm{mg}$ protein. This represents $<10 \%$ of the $\left[{ }^{14} \mathrm{C}\right]$ acetate uptake observed in astrocytes in $15 \mathrm{sec}$.

If diffusion can account maximally for only $20 \%$ of the association of acetate with the synaptosomes, what is the remainder attributable to? The association of $\left[{ }^{14} \mathrm{C}\right]$ sucrose and $\left[{ }^{14} \mathrm{C}\right]$ acetate with varying concentrations of synaptosomes was compared. Sucrose does not readily cross cell membranes and is therefore a useful marker for the extracellular space. $\left[{ }^{14} \mathrm{C}\right]$ Sucrose and $\left[{ }^{14} \mathrm{C}\right]$ acetate were found to be distributed equally in proportion to the concentration of synaptosomal protein. The association of $\left[{ }^{14} \mathrm{C}\right]$ sucrose and $\left[{ }^{14} \mathrm{C}\right]$ acetate with the synaptosomes presumably represents entrapment of extracellular fluid in the pellet produced by centrifugation of tissue vesicles through an oil layer. The volume of the extracellular space calculated from the $\left[{ }^{14} \mathrm{C}\right]$ sucrose measurements is $14.1 \pm 2.0 \mu \mathrm{l} / \mathrm{mg}$ protein. With an extracellular concentration of acetate of $0.2 \mathrm{~mm}$, the amount of acetate entrapped in the extracellular sucrose space would be $2.8 \pm 0.4 \mathrm{nmol} / \mathrm{mg}$ protein. This value is $76 \%$ of the total acetate associated with synaptosomes $\left(3.7 \pm 0.3 \mathrm{nmol} / \mathrm{mg}\right.$ protein at $\left.4^{\circ} \mathrm{C}\right)$. Therefore, the major proportion of the $\left[{ }^{14} \mathrm{C}\right]$ acetate associated with synaptosomes is caused by entrapment in the extracellular space, and the remainder can be accounted for by diffusion. 


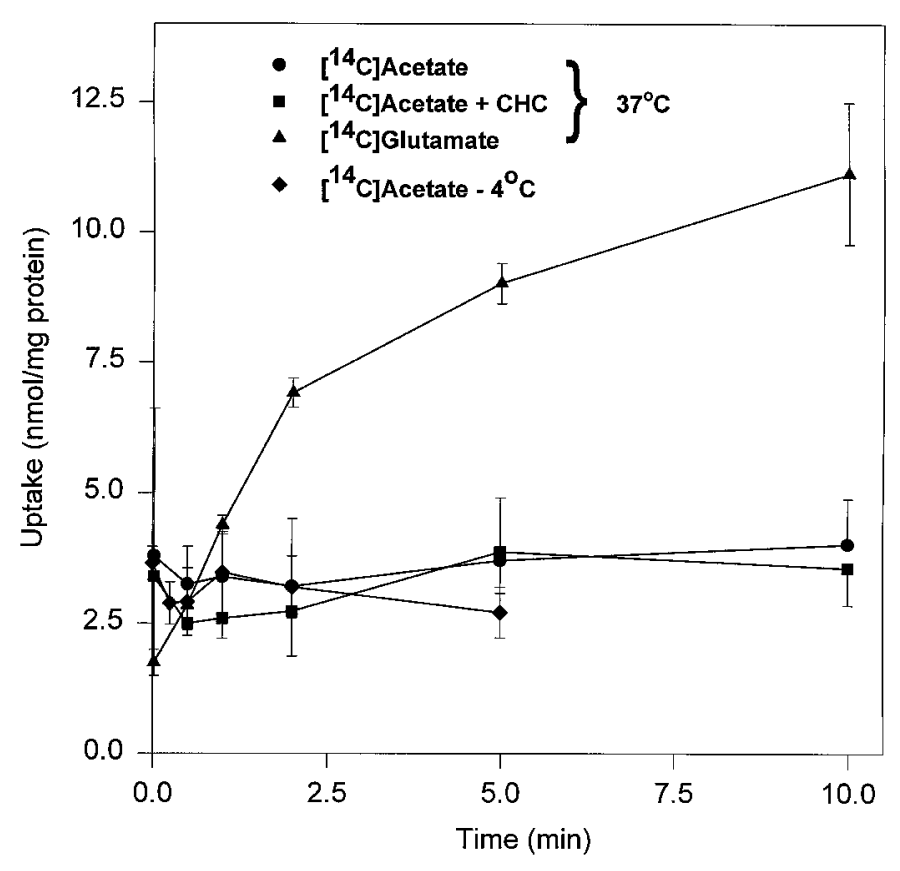

Figure 7. Synaptosomes incubated at 4 or $37^{\circ} \mathrm{C}$ do not increase their uptake of $\left[{ }^{14} \mathrm{C}\right]$ acetate over time. The observed association of $\left[{ }^{14} \mathrm{C}\right]$ label at $37^{\circ} \mathrm{C}$ is not altered by addition of $10 \mathrm{~mm} \mathrm{CHC}$. Synaptosomal suspensions were incubated with $0.2 \mathrm{~mm}\left[{ }^{14} \mathrm{C}\right]$ acetate alone at 4 or $37^{\circ} \mathrm{C}$ in the presence or absence of $\mathrm{CHC}$. At the indicated times, aliquots of the suspension were diluted into cold buffer containing $10 \mathrm{~mm}$ CHC and immediately centrifuged through a layer of silicone oil at room temperature. Synaptosomes from the same preparation were kept on ice in 0.32 M sucrose until the acetate-uptake experiments were completed and then were incubated with $0.01 \mathrm{~mm}\left[{ }^{14} \mathrm{C}\right]$ glutamate at $37^{\circ} \mathrm{C}$. Data points represent the mean $\pm \mathrm{SD}$ of five determinations. The $4^{\circ} \mathrm{C}$ experiment was repeated two additional times and the same results were obtained. There were no significant differences in $\left[{ }^{14} \mathrm{C}\right]$ acetate uptake between individual time points or between synaptosomes incubated with or without $\mathrm{CHC}$.

Extracellular entrapment and diff usion of $\left[{ }^{14} \mathrm{C}\right]$ acetate impose a relatively high background on the study of nondiff usional acetate uptake by synaptosomes. The question then is what is the minimum detectable increase in uptake in this system? Astrocytes demonstrate a continuous increase in $\left[{ }^{14} \mathrm{C}\right]$ acetate labeling for up to $1 \mathrm{~min}$. With synaptosomes, it should be possible to detect a $25 \%$ increase (from 3.7 to $4.7 \mathrm{nmol} / \mathrm{mg}$ protein) given the small variance $(\mathrm{SD}, 0.3)$ in uptake measurements at $4^{\circ} \mathrm{C}$. If this increased uptake occurred in $1 \mathrm{~min}$, it would represent a rate of uptake by synaptosomes of $1 \mathrm{nmol} / \mathrm{min}$ per milligram of protein. Therefore, astrocytes accumulate acetate at least 10 times faster than synaptosomes. There is evidence in the literature that synaptosomes are relatively impermeant to acetate. Treating synaptosomes with ether to increase their permeability increased the rate of acetylcholine production from acetate 10-fold (Tuček, 1967a).

The extracellular volume for synaptosomes obtained from the $\left[{ }^{14} \mathrm{C}\right]$ sucrose measurements $(14.1 \pm 2.0 \mu \mathrm{l} / \mathrm{mg}$ protein $)$ seemed too large when compared with published values. The volume obtained by Pastuszko et al. (1982) was $5.4 \pm 0.9 \mu \mathrm{l} / \mathrm{mg}$ protein using $\left[{ }^{14} \mathrm{C}\right]$ polyethylene glycol as an extracellular marker. This was based on protein measured by the method of Lowry et al. (1951). The Bradford (1976) assay was used in all our uptake experiments because of the small amounts of protein in the wells containing astrocytes. The synaptosomal protein contents were reanalyzed with the Lowry method and found to be approxi-

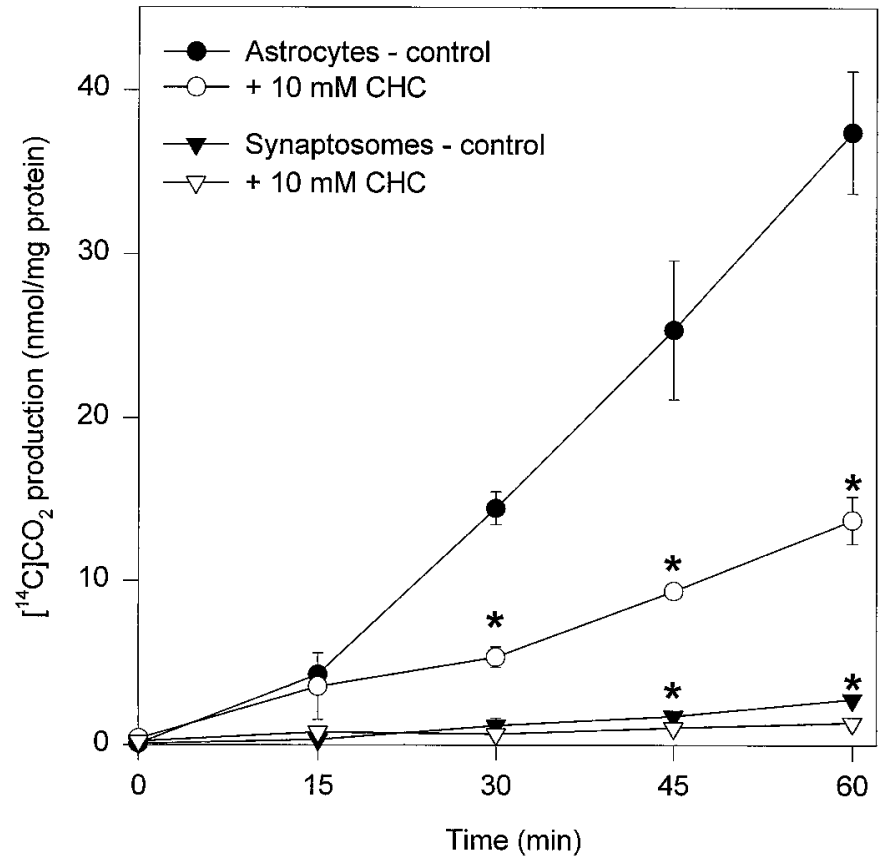

Figure 8. Effect of $\mathrm{CHC}$ on ${ }^{14} \mathrm{CO}_{2}$ production from $1-\left[{ }^{14} \mathrm{C}\right]$ acetate in cortical astrocytes and synaptosomes. Both preparations were incubated with $0.2 \mathrm{~mm}$ sodium acetate under identical conditions in an oxygenated, glucose-containing, HEPES-buffered HBSS at $37^{\circ} \mathrm{C}$ for the indicated times. CHC (10 mM) was added to the tissues at the same time as the $1-\left[{ }^{14} \mathrm{C}\right]$ acetate. Data points represent the mean \pm SD of four determinations. *Significant differences between $\mathrm{CHC}$ and control-treated astrocytes or synaptosomes at the times indicated; $p<0.05$. This experiment was repeated two additional times, and the same results were obtained.

mately twice as high as those analyzed by the Bradford method. The recalculated extracellular space was $7.6 \pm 1.0 \mu \mathrm{l} / \mathrm{mg}$ protein, which is similar to other published values.

\section{Effect of CHC on acetate metabolism to ${ }^{14} \mathrm{CO}_{2}$ in astrocytes and synaptosomes}

Astrocytes and synaptosomes incubated at $37^{\circ} \mathrm{C}$ in oxygenated glucose-containing buffer both produced significantly less ${ }^{14} \mathrm{CO}_{2}$ from $\left[{ }^{14} \mathrm{C}\right]$ acetate in the presence of $10 \mathrm{~mm} \mathrm{CHC} \mathrm{(Fig.} \mathrm{8).} \mathrm{Thus,}$ the acetate that is converted to ${ }^{14} \mathrm{CO}_{2}$ is accumulated primarily by the monocarboxylate transport process. The failure to completely block ${ }^{14} \mathrm{CO}_{2}$ production by astrocytes with $\mathrm{CHC}$ may be attributable to the fact that $\left[{ }^{14} \mathrm{C}\right]$ acetate uptake is not completely inhibited by $10 \mathrm{~mm} \mathrm{CHC}$ (Fig. 6). The low level of ${ }^{14} \mathrm{CO}_{2}$ production in synaptosomes relative to astrocytes $(5 \%)$ is consistent with the low level of acetate uptake by synaptosomes. Some of the ${ }^{14} \mathrm{CO}_{2}$ production also may be attributable to the very small glial contamination of synaptosomes.

\section{DISCUSSION}

The present study demonstrates first that astrocytes produce ${ }^{14} \mathrm{CO}_{2}$ from $1-\left[{ }^{14} \mathrm{C}\right]$ acetate much more rapidly than do synaptosomes. The difference in acetate utilization was not attributable to the selective cellular localization of acetyl-CoA synthetase, because acetyl-CoA synthetase activity is greater in synaptosomes than in astrocytes. The preferential utilization of acetate by astrocytes is attributable to much more rapid uptake of acetate by astrocytes than synaptosomes. Transport of acetate appears to be mediated by a carrier having many properties in common with the proton-coupled monocarboxylate transporter. Synaptosomes 
do not have detectable acetate uptake other than that caused by diffusion under any of the conditions used to measure uptake by astrocytes. The metabolism of acetate to $\mathrm{CO}_{2}$ was significantly inhibited by the specific monocarboxylate transport inhibitor $\mathrm{CHC}$ in both preparations.

For these studies, functionally intact and relatively pure preparations were required to allow direct comparison of astrocytes and neurons. Two different preparations were used: rat cortical astrocytes in primary cell culture and rat brain cortical synaptosomes. Neuronal cell cultures are not of sufficient density to permit reliable detection of acetate transport, and the presence of astrocytes in such cultures would compromise the goal of the study. Contamination with glia and extrasynaptosomal mitochondria is minimal in the synaptosomal preparation used (Dodd et al., 1981; Löscher et al., 1985). Our previous studies confirmed that the astrocytic contamination was low because the rate of glutamine production in these synaptosomes (Battaglioli and Martin, 1990) is $<5 \%$ of that of cultured astrocytes (Waniewski, 1992). It was important also to eliminate free mitochondria, because they may accumulate and metabolize acetate.

Earlier studies demonstrated that there was much more incorporation of acetate carbon into glutamate, glutamine, and TCA cycle intermediates in astrocytes than in neurons (Sonnewald et al., 1993). The current study demonstrates that acetate metabolism to $\mathrm{CO}_{2}$ is much more rapid in astrocytes than synaptosomes. The metabolism of other energy substrates to $\mathrm{CO}_{2}$ has been compared in similar preparations (McKenna et al., 1993). The rate of ${ }^{14} \mathrm{CO}_{2}$ production from $\left[{ }^{14} \mathrm{C}\right]$ acetate by astrocytes in the present study, $26 \mathrm{nmol} / \mathrm{hr}$ per milligram of protein with $0.2 \mathrm{~mm}$ acetate is faster than the rate reported for any of the tested substrates at $1 \mathrm{~mm}$. These included malate, lactate, glucose, glutamine, and 3-hydroxybutyrate (McKenna et al., 1993).

Both astrocytes and synaptosomes have significant and comparable levels of acetyl-CoA synthetase activity. The similarity of the activity in these two preparations to that found in whole cortex homogenates argues against the specific cellular compartmentation of this enzyme. Other investigators have reported high activities for acetyl-CoA synthetase in mammalian brain synaptosomes (Tuček, 1967b; Szutowicz and Łysiak, 1980), but this is the first direct comparison of acetyl-CoA synthetase activity in astrocytes and synaptosomes. Thus, the preferential utilization of acetate by astrocytes is not explained by differences in the cellular distribution of acetyl-CoA synthetase.

Research on acetate transport in the nervous system has focused primarily on movement across the blood-brain barrier; previous studies suggest that uptake occurs by passive diffusion (Oldendorf, 1973; Terasaki et al., 1991). Such nonspecific entry would not likely be differentially expressed in neurons versus astrocytes. Our findings of time dependence, saturability, and inhibition by selective inhibitors provide evidence that intact astrocytes accumulate acetate by a specific carrier mechanism. This carrier displays many of the properties described for the proton-coupled monocarboxylate transporter. Uptake is transaccelerated by preloading cells with acetate or L-lactate, and the pharmacology of inhibition is similar to that of the monocarboxylate transporters studied in erythrocytes, liver, skeletal muscle, and heart cells (Poole and Halestrap, 1993), and the cloned transporters MCT1 and MCT2 (Garcia et al., 1994).

Fluoroacetate is toxic because it is metabolized to fluorocitrate, which inhibits the aconitase step in the TCA cycle (Peters, 1963). Fluoroacetate has been shown to selectively inhibit the TCA cycle of astrocytes over neurons (Keyser and Pellmar, 1994), but the mechanism for its selectivity is not known. The chemical similarity of acetate and fluoroacetate and the ability of fluoroacetate to effectively inhibit acetate uptake suggests that it may also be accumulated preferentially by astrocytes.

$\mathrm{CHC}$ is an effective inhibitor of $\left[{ }^{14} \mathrm{C}\right]$ acetate uptake but does not inhibit completely. One possible explanation for this is that acetate enters astrocytes by an additional pathway. The partial inhibition produced by DIDS and ethacrynic acid suggests that some of the acetate may enter by another carrier such as an anion exchanger.

The transport of lactate has been compared previously in astrocytes and neurons. Lactate efflux from astrocytes is seven times faster than from neurons (Walz and Mukerji, 1988). Although efflux was not blocked by $\mathrm{CHC}$, the authors concluded that lactate efflux occurred by proton-lactate cotransport. Transport measured by lactate-induced acidification has shown that cultured neurons and astrocytes have the same $K_{\mathrm{m}}(0.38 \mathrm{~mm})$, but neurons have an $80 \%$ higher $V_{\max }$ (Nedergaard and Goldman, 1993). CHC inhibited $\left[{ }^{14} \mathrm{C}\right]$ lactate transport in neuronal cultures (Dringen et al., 1993) and C6 glioma cells but not in astrocyte cultures (Dringen et al., 1995). Lactate transport by rat astrocytes recently has been shown to be inhibited by $\mathrm{CHC}$ and to have kinetic properties similar to those described here for acetate (Bröer et al., 1997). Thus, it appears that lactate transport is not restricted to either astrocytes or neurons.

The role of monocarboxylate transport in the nervous system is not well understood. Tsacopoulos and Magistretti (1996) have proposed a mechanism in which astrocytes metabolize glucose to lactate. Neurons accumulate lactate and metabolize it for use in the TCA cycle. If acetate and lactate are carried on the same transporter, it is not clear why neurons would accumulate lactate but not acetate. Although the evidence is indirect, our transacceleration experiments indicate that astrocytes also transport L-lactate. Two monocarboxylate transporters have been cloned (Garcia et al., 1994) that differ in organ distribution and have slightly different substrate and inhibitor affinities. Recent evidence indicates that MCT1 is expressed in astrocytes and MCT2 in neurons (Bröer et al., 1997). Additional members of this family may exist with differing substrate specificities (e.g., a lactate transporter in neurons that does not transport acetate). Under physiological conditions, the monocarboxylate transporters may be regulated by the transacceleration mechanism. Cells that produce lactate may have a greater capacity to accumulate acetate by heteroexchange with lactate. Cells that rapidly metabolize lactate may not be capable of such transacceleration. Similarly, cells that metabolize pyruvate via the TCA cycle may not transaccelerate acetate uptake. Mouse cortical astrocytes and neurons are capable of rapidly oxidizing pyruvate to $\mathrm{CO}_{2}$ (Fitzpatrick et al., 1988). Such a process does not likely explain why pyruvate did not transaccelerate acetate uptake in the present study because metabolism was minimized by the low incubation temperature. Pyruvate may not be accumulated by astrocytes.

Several lines of evidence suggest that acetate transport may be important in the nervous system. Extracellular acetate in the brain may be derived from at least three sources. Transport from the peripheral circulation is possible because acetate is produced by anaerobic bacteria in the gut (Wolin and Miller, 1983) and is normally present at about $0.2-0.3 \mathrm{~mm}$ in the blood. Blood levels are influenced by diet and the microbial species in the intestine. Acetate and other minor short-chain fatty acids generated in the gut are used as an energy source and account for $5-10 \%$ of total caloric use in humans (McNeil, 1984). 
Ethanol is metabolized to acetate. Plasma acetate levels increased from 0.3 to $1 \mathrm{~mm}$ for $4 \mathrm{hr}$ after a single intravenous dose of $0.5 \mathrm{gm} / \mathrm{kg}$ ethanol in humans (Orrego et al., 1988). Although brain acetate levels have not been measured after alcohol consumption, ${ }^{14} \mathrm{C}$ from intraperitoneally injected $\left[{ }^{14} \mathrm{C}\right]$ ethanol is incorporated into glutamate, glutamine, and GABA in hamster brain (Roach and Reese, 1972).

Finally, acetylcholine (ACh) is rapidly metabolized by extracellular cholinesterases to acetate and choline in the brain. If cholinergic neurons are inefficient in recapturing acetate lost during ACh release, they would tend to consume acetyl-CoA to maintain their supply of ACh. A cycle may exist, like the glutamine cycle, that allows for the efficient reutilization by astrocytes of acetate lost from cholinergic neurons.

In conclusion, evidence is provided here for a previously undescribed metabolic process in the nervous system. Acetate is selectively accumulated from the extracellular space by a monocarboxylate transporter-like process in astrocytes, in which it is metabolized to $\mathrm{CO}_{2}$, providing a potential source of energy in the brain. Incorporation of $\left[{ }^{13} \mathrm{C}\right]$ from acetate into glutamine is used to study "glial" metabolism in the nervous system (BadarGoffer et al., 1990; Cerdan et al., 1990; Chapa et al., 1995; Sonnewald et al., 1996). The present results provide support for this approach by demonstrating that the biochemical basis for the selective utilization of acetate is attributable to much greater uptake by astrocytes than by neurons.

\section{REFERENCES}

Badar-Goffer RS, Bachelard HS, Morris PG (1990) Cerebral metabolism of acetate and glucose studied by ${ }^{13} \mathrm{C}$-n.m.r. spectroscopy: a technique for investigating metabolic compartmentation in the brain. Biochem J 266:133-139.

Battaglioli G, Martin DL (1990) Stimulation of synaptosomal $\gamma$-aminobutyric acid synthesis by glutamate and glutamine. J Neurochem 54:1179-1187.

Bradford MM (1976) A rapid and sensitive method for the quantitation of microgram quantities of protein utilizing the principle of protein-dye binding. Anal Biochem 72:248-254.

Bröer S, Rahman B, Pellegri G, Pellerin L, Martin J-L, Verleysdonk S, Hamprecht B, Magistretti PJ (1997) Comparison of lactate transport in astroglial cells and monocarboxylate transporter 1 (MCT1) expressing Xenopus laevis oocytes. J Biol Chem 272:30096-30102.

Cerdan S, Künnecke B, Seelig J (1990) Cerebral metabolism of [1,2${ }^{13} \mathrm{C}_{2}$ ] $\mathrm{S}$,etate as detected by in vivo and in vitro ${ }^{13} \mathrm{C} \mathrm{NMR}$. J Biol Chem 265:12916-12926.

Chapa F, Künnecke B, Calvo R, Escobar del Rey F, Morreale de Escobar G, Cerdán S (1995) Adult-onset hypothyroidism and the cerebral metabolism of $\left(1,2-{ }^{13} \mathrm{C}_{2}\right)$ acetate as detected by ${ }^{13} \mathrm{C}$ nuclear magnetic resonance. Endocrinology 136:296-305.

Dodd PR, Hardy JA, Oakley AE, Edwardson JA, Perry EK, Delaunoy JP (1981) A rapid method for preparing synaptosomes: comparison, with alternative procedures. Brain Res 226:107-118.

Dringen R, Wiesinger H, Hamprecht B (1993) Uptake of L-lactate by cultured rat brain neurons. Neurosci Lett 163:5-7.

Dringen R, Peters H, Wiesinger H, Hamprecht B (1995) Lactate transport in cultured glial cells. Dev Neurosci 17:63-69.

Fitzpatrick SM, Cooper AJL, Hertz L (1988) Effects of ammonia and methylene-DL-aspartate on the oxidation of glucose and pyruvate by neurons and astrocytes in primary culture. J Neurochem 51:1197-1203.

Fonnum F (1985) Determination of transmitter amino acid turnover. In: Neuromethods, Series 1: Neurochemistry, Vol 3: Amino Acids (Boulton AA, Baker GB, Wood JD, eds), pp 201-237. Clifton, NJ: Humana.

Frangakis MV, Kimelberg HK (1984) Dissociation of neonatal rat brain by dispase for preparation of primary astrocyte cultures. Neurochem Res 9:1689-1698.

Gale K, Iadarola MJ (1980) Seizure protection and increased nerveterminal GABA: delayed effects of GABA transaminase inhibition. Science 208:288-291.

Garcia CK, Goldstein JL, Pathak RK, Anderson RGW, Brown MS
(1994) Molecular characterization of a membrane transporter for lactate, pyruvate, and other monocarboxylates: implications for the Cori Cycle. Cell 76:865-873.

Haldorsen KM (1977) Vanadium pentoxide in sulphuric acid, a general chromogenic spray reagent for carbohydrates. J Chromatogr 134:467-476.

Halestrap AP, Denton RM (1974) Specific inhibition of pyruvate transport in rat liver mitochondria and human erythrocytes by $\alpha$-cyano-4hydroxycinnamate. Biochem J 138:313-316.

Keyser DO, Pellmar TC (1994) Synaptic transmission in the hippocampus: critical role for glial cells. Glia 10:237-243.

Löscher W, Böhme G, Müller F, Pagliusi S (1985) Improved method for isolating synaptosomes from 11 regions of one rat brain: electron microscope and biochemical characterization and use in the study of drug effects on nerve terminal $\gamma$-aminobutyric acid in vivo. J Neurochem 45:879-889.

Lowry OH, Rosebrough NJ, Farr AL, Randall RJ (1951) Protein measurement with the Folin phenol reagent. J Biol Chem 193:265-275.

Marchbanks RM (1975) The chloride content, anion deficit and volume of synaptosomes. J Neurochem 25:463-470.

Martin DL, Shain W (1979) High affinity transport of taurine and $\beta$-alanine and low affinity transport of $\gamma$-aminobutyric acid by a single transport system in cultured glioma cells. J Biol Chem 254:7076-7084.

McKenna MC, Tildon JT, Stevenson JH, Boatright R, Huang S (1993) Regulation of energy metabolism in synaptic terminals and cultured rat brain astrocytes: differences revealed using aminooxyacetate. Dev Neurosci 15:320-329.

McNeil NI (1984) The contribution of the large intestine to energy supplies in man. Am J Clin Nutr 39:338-342.

Minchin MCW, Beart PM (1975) Compartmentalization of amino acid metabolism in the rat dorsal root ganglion: a metabolic and autoradiographic study. Brain Res 83:437-449.

Muir D, Berl S, Clarke DD (1986) Acetate and fluroacetate as possible markers for glial metabolism in vivo. Brain Res 380:336-340.

Nedergaard M, Goldman SA (1993) Carrier-mediated transport of lactic acid in cultured neurons and astrocytes. Am J Physiol 265:R282-R289.

Norenberg MD, Martinez-Hernandez A (1979) Fine structural localization of glutamine synthetase in astrocytes of rat brain. Brain Res 161:303-310.

Oldendorf WH (1973) Carrier mediated blood-brain barrier transport of short-chain monocarboxylic organic acids. Am J Physiol 224:1450-1453.

O’Neal RM, Koeppe RE (1966) Precursors in vivo of glutamate, aspartate and their derivatives of rat brain. J Neurochem 13:835-847.

Orrego H, Carmichael FJ, Israel Y (1988) New insights on the mechanism of the alcohol-induced increase in portal blood flow. Can J Physiol 66:1-9.

Pastuszko A, Wilson DF, Erecinska M (1982) Energetics of $\gamma$-aminobutyrate transport in rat brain synaptosomes. J Biol Chem 257:7514-7519.

Peters RA (1963) Lethal synthesis and carbon-fluorine compounds. In: Biochemical lesions and lethal synthesis (Alexander P, Bacq ZM, eds), pp 88-130. New York: Macmillan.

Poole RC, Halestrap AP (1993) Transport of lactate and other monocarboxylates across mammalian plasma membranes. Am J Physiol 264:C761-C782.

Reijnierse GLA, Veldstra H, Van Den Berg CJ (1975) Short-chain fatty acid synthases in brain: subcellular localization and changes during development. Biochem J 152:477-484.

Roach MK, Reese WN (1972) $\left[2-{ }^{14} \mathrm{C}\right]$ Ethanol as a precursor of glutamine, glutamate, $\gamma$-aminobutyric acid and aspartate in hamster brain in vivo. Biochem Pharmacol 21:2013-2019.

Roughan PG, Ohlrogge JB (1994) On the assay of acetyl-CoA synthetase activity in chloroplasts and leaf extracts. Anal Biochem 216:77-82.

Sánchez-Armass S, Martínez-Zaguilán R, Martínez GM, Gillies RJ (1994) Regulation of $\mathrm{pH}$ in rat brain synaptosomes. I. Role of sodium, bicarbonate, and potassium. J Neurophysiol 71:2236-2248.

Shiroya T, Fukunaga R, Akashi K, Shimada N, Takagi Y, Nishino T, Hara M, Inagaki C (1989) An ATP-driven $\mathrm{Cl}^{-}$pump in the brain. J Biol Chem 264:17416-17421.

Sonnewald U, Westergaard N, Schousboe A, Svendsen JS, Unsgård G, Petersen SB (1993) Direct demonstration by $\left[{ }^{13} \mathrm{C}\right]$ NMR spectroscopy that glutamine from astrocytes is a precursor for GABA synthesis in neurons. Neurochem Int 22:19-29. 
Sonnewald U, Therrien G, Butterworth RF (1996) Portacaval anastomosis results in altered neuron-astrocytic metabolic trafficking of amino acids: evidence from ${ }^{13} \mathrm{C}$-NMR studies. J Neurochem 67:1711-1717.

Szutowicz A, Łysiak W (1980) Regional and subcellular distribution of ATP-citrate lyase and other enzymes of acetyl-CoA metabolism in rat brain. J Neurochem 35:775-785.

Terasaki T, Takakuwa S, Moritani S, Tsuji A (1991) Transport of monocarboxylic acids at the blood-brain barrier: studies with monolayers of primary cultured bovine brain capillary endothelial cells. J Pharmacol Exp Ther 258:932-937.

Tildon JT, McKenna MC, Stevenson J, Couto R (1993) Transport of L-lactate by cultured rat brain astrocytes. Neurochem Res 18:177-184.

Tsacopoulos M, Magistretti PJ (1996) Metabolic coupling between glia and neurons. J Neurosci 16:877-885.

Tuček S (1967a) Observations on the subcellular distribution of choline acetyltransferase in the brain tissue of mammals and comparisons of acetylcholine synthesis from acetate and citrate in homogenates and nerve-ending fractions. J Neurochem 14:519-529.

Tuček S (1967b) Subcellular distribution of acetyl-CoA synthetase, ATP citrate lyase, citrate synthetase, choline acetyltransferase, fumarate hydratase and lactate dehydrogenase in mammalian brain tissue. J Neurochem 14:531-545.
Van Den Berg CJ, Kržalić LJ, Mela P, Waelsch H (1969) Compartmentation of glutamate metabolism in brain: evidence for the existence of two different tricarboxylic acid cycles in brain. Biochem J 113:281-290.

Walter A, Gutknecht J (1984) Monocarboxylic acid permeation through lipid bilayer membranes. J Membr Biol 77:255-264.

Walz W, Mukerji S (1988) Lactate release from cultured astrocytes and neurons: a comparison. Glia 1:366-370.

Waniewski RA (1992) Physiological levels of ammonia regulate glutamine synthesis from extracellular glutamate in astrocyte cultures. J Neurochem 58:167-174.

Waniewski RA, Martin DL (1983) Selective inhibition of glial versus neuronal uptake of L-glutamic acid by SITS. Brain Res 268:390-394.

Waniewski RA, Martin DL, Shain W (1991) Isoproterenol selectively releases endogenous and $\left[{ }^{14} \mathrm{C}\right]$-labelled taurine from a single cytosolic compartment in astroglial cells. Glia 4:83-90.

Wolin MJ, Miller TL (1983) Carbohydrate fermentation. In: Human intestinal flora in health and disease (Hentges DA, ed), pp 147-165. New York: Academic.

Wuttke WA, Walz W (1990) Sodium- and bicarbonate-independent regulation of intracellular $\mathrm{pH}$ in cultured mouse astrocytes. Neurosci Lett 117:105-110. 